\title{
Installation and Commissioning of the Netzsch Skimmer
}

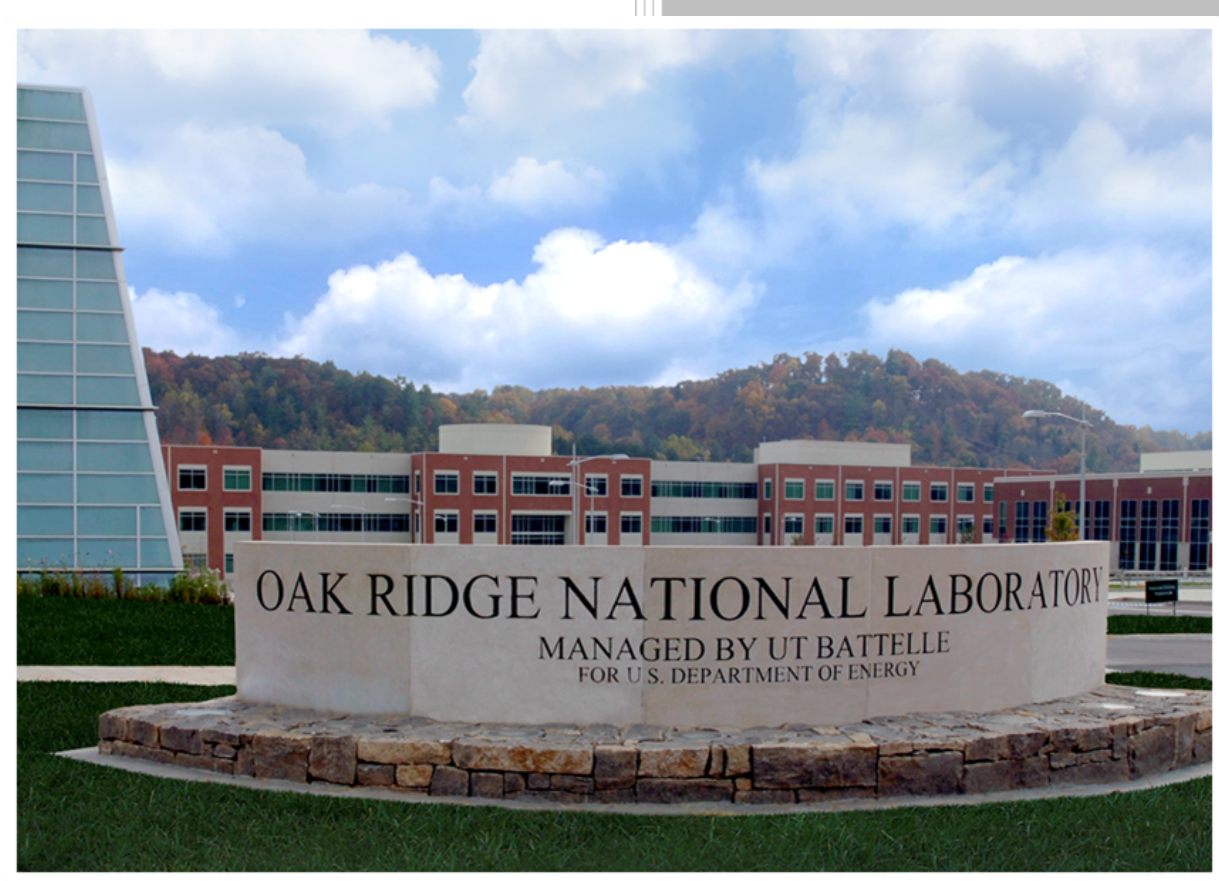
J. McFarlane
J. W. McMurray
A. McAlister

August 2019 


\section{DOCUMENT AVAILABILITY}

Reports produced after January 1, 1996, are generally available free via US Department of Energy (DOE) SciTech Connect.

Website www.osti.gov

Reports produced before January 1, 1996, may be purchased by members of the public from the following source:

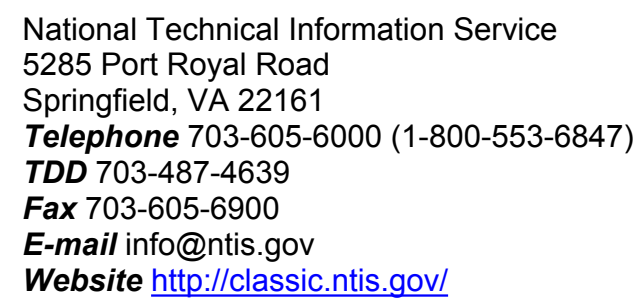

Reports are available to DOE employees, DOE contractors, Energy Technology Data Exchange representatives, and International Nuclear Information System representatives from the following source:

Office of Scientific and Technical Information

PO Box 62

Oak Ridge, TN 37831

Telephone 865-576-8401

Fax 865-576-5728

E-mail reports@osti.gov

Website http://www.osti.gov/contact.html

This report was prepared as an account of work sponsored by an agency of the United States Government. Neither the United States Government nor any agency thereof, nor any of their employees, makes any warranty, express or implied, or assumes any legal liability or responsibility for the accuracy, completeness, or usefulness of any information, apparatus, product, or process disclosed, or represents that its use would not infringe privately owned rights. Reference herein to any specific commercial product, process, or service by trade name, trademark, manufacturer, or otherwise, does not necessarily constitute or imply its endorsement, recommendation, or favoring by the United States Government or any agency thereof. The views and opinions of authors expressed herein do not necessarily state or reflect those of the United States Government or any agency thereof. 
Isotope and Fuel Cycle Technology Division

\section{INSTALLATION AND COMMISSIONING OF THE NETZSCH SKIMMER}

J. McFarlane

J. W. McMurray

A. McAlister

August 2019

Prepared by

OAK RIDGE NATIONAL LABORATORY

Oak Ridge, TN 37831-6283

managed by

UT-BATTELLE, LLC

for the

US DEPARTMENT OF ENERGY

under contract DE-AC05-00OR22725 



\section{CONTENTS}

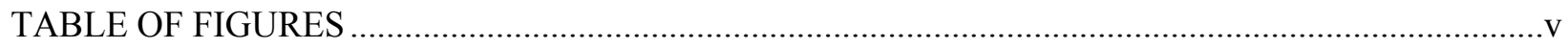

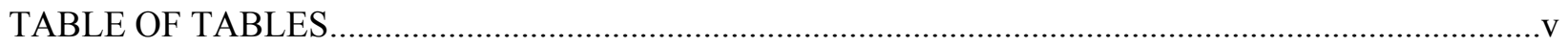

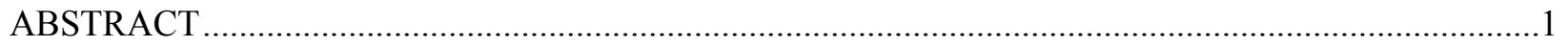

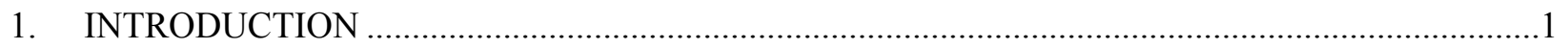

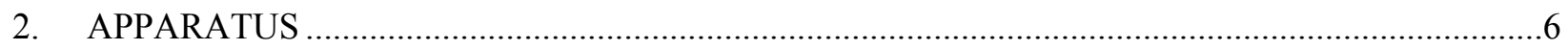

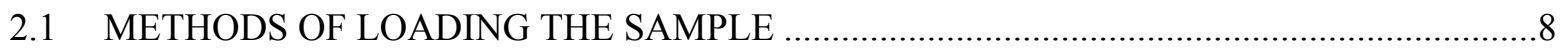

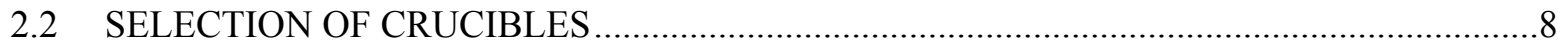

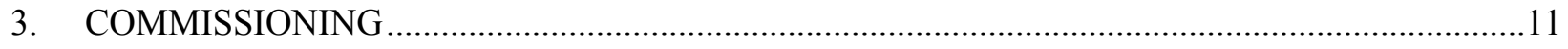

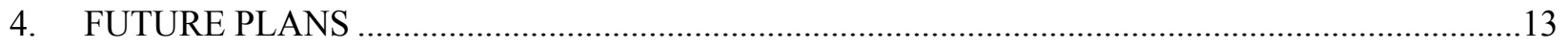

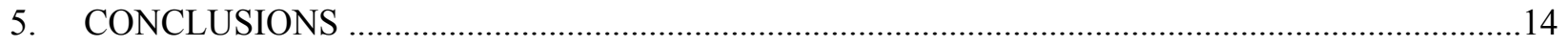

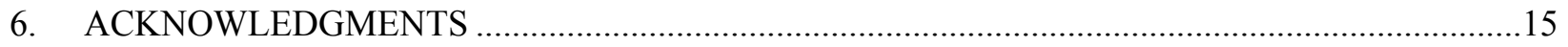

6.1 CONTACT INFORMATION FOR NETZSCH

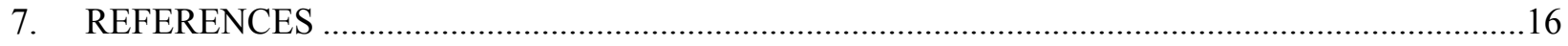





\section{TABLE OF FIGURES}

Figure 1. Schematic of Netzsch skimmer.

Figure 2. TG-DSC sample carrier system (on left) and heat shield (on right)........................................3

Figure 3. Mass loss test with sealable DSC crucibles up to $700^{\circ} \mathrm{C}$, with mass trace in green and temperature ramp in red (from a standard Netzsch simultaneous thermal analyzer)...

Figure 4. Elements of Netzsch skimmer including the furnace/measuring unit, control units for the mass spectrometer, balance, vacuum-water-power, pumps, and dedicated computer................6

Figure 5. Photograph of the Netzsch skimmer setup at Oak Ridge National Laboratory ............................7

Figure 6. Netzsch STA furnace showing one of the two skimmers with the furnace dropped from the mating with the mass spectrometer. ................................................................................

Figure 7. High-pressure, sealable $\mathrm{Ni}-\mathrm{Cr}$ alloy crucible with gold-plated pan............................................8

Figure 8. Schematic of sealed molybdenum crucible and electron-beam welded crucible

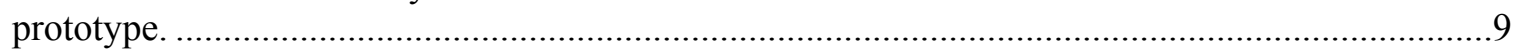

Figure 9. Mass loss trace from the heating of calcium oxalate in commissioning the skimmer................11

Figure 10. Ion signal as a function of temperature for calcium oxalate ..................................................12

\section{TABLE OF TABLES}

Table 1. Selected sample crucibles for the Netzsch STA. ................................................................10

Table 2. Possible salt mixtures for near-term study in the skimmer........................................................13 



\begin{abstract}
The DOE molten salt reactor (MSR) program has been focusing on the thermochemistry and transport properties of fuel, diluent/carrier, coolant, flush, and reprocessing salts proposed for various molten salt reactor technologies. Data from the chemistry project inform models of salt behavior used in dynamic models of nuclear salt reactors, for both high fidelity and systems simulations. Reactor and salt processing systems operate well above salt melting points $\left(>600^{\circ} \mathrm{C}\right)$, so salt behavior can be well described by thermodynamics. However, much is not known about salt systems that contain two, three, or even more components. The Netzsch skimmer (commissioned this year) can be used in several configurations to collect data on molten systems. The skimmer uses mass spectrometry coupled with a thermogravimetric analyzer to accurately analyze systems up to $2000^{\circ} \mathrm{C}$. Because the mass analyzer is coupled directly to the furnace through two nested orifices, there are no losses due to condensation. As a thermogravimetric analyzer, the skimmer measures weight loss and reaction energies simultaneously with evolved gas analysis. The mass spectrometry identifies gas phase species, and these volatility measurements can be used to derive vapor pressures. The skimmer was purchased in fiscal year 2018, delivered in April, installed in May 2019, and now is fully operational as verified by the analysis of known standards. The skimmer is unique because it will be available for study of salt systems that contain actinides or beryllium, although the additional work control to accommodate these hazards is still under review.
\end{abstract}

\title{
1. INTRODUCTION
}

Molten salt reactors that run at elevated temperatures, about $650^{\circ} \mathrm{C}$, rely on salt constituents being chemically stable and nonvolatile under normal operating conditions. Although many thermodynamic data have been collected for single salt constituents and two-component systems, the molten salt systems being proposed often are mixtures of several salts. Some of these contain the fissionable or fertile material, which lack thermodynamic data because of the need for special facilities to do the measurements. A dedicated thermogravimetric analyzer coupled with off-gas analysis allows us to make measurements on actinidebearing salts in support of the advanced reactor campaign's molten salt program. In addition, the instrument will be available for measurements on beryllium-bearing salts that often have more stringent handling requirements than low-level radiological material, such as depleted uranium.

Although salts for MSRs are meant to be nonvolatile under normal operating conditions, this may not be the case if temperatures rise during off-normal events. Excursions to greater than $2000^{\circ} \mathrm{C}$, such as those predicted in severe accidents involving light water reactor fuel, are not possible with MSRs. However, the salt may heat to $1000^{\circ} \mathrm{C}$ if flow blockage occurs, impairing heat transfer. Salt components, particularly those arising from fission or from corrosion processes, may become volatile. The chemistry of salt components can be predicted by thermodynamics, using Gibbs free energy minimization. The skimmer will allow us to measure the activity of the salt components under the redox conditions in the salt environment and the volatility as a function of temperature. These data can be used to generate expressions for Gibbs free energy for components of salt mixtures.

A schematic of the skimmer is given in Figure 1, which shows the furnace that can heat the sample up to $2000^{\circ} \mathrm{C}$ in a protective or reactive cover gas. Mass is lost from the sample through vaporization shown as red dots, and the mass loss is recorded by a balance. With the cover gas, the pressure in the furnace is a low vacuum or a few millibar. Simultaneously, the gas that evolves from the sample along with the cover gas is passed through two orifices (or skimmers) before it enters the mass spectrometer. The vacuum system between the two orifices is independently pumped, and the mass spectrometer is pumped to a high vacuum. Thus, the ionizer in the mass spectrometer has a direct line of sight to the sample cell. Mass selection through time-of-flight mass spectrometry allows detection of small amounts of evolved species in the large fraction of cover gas. 


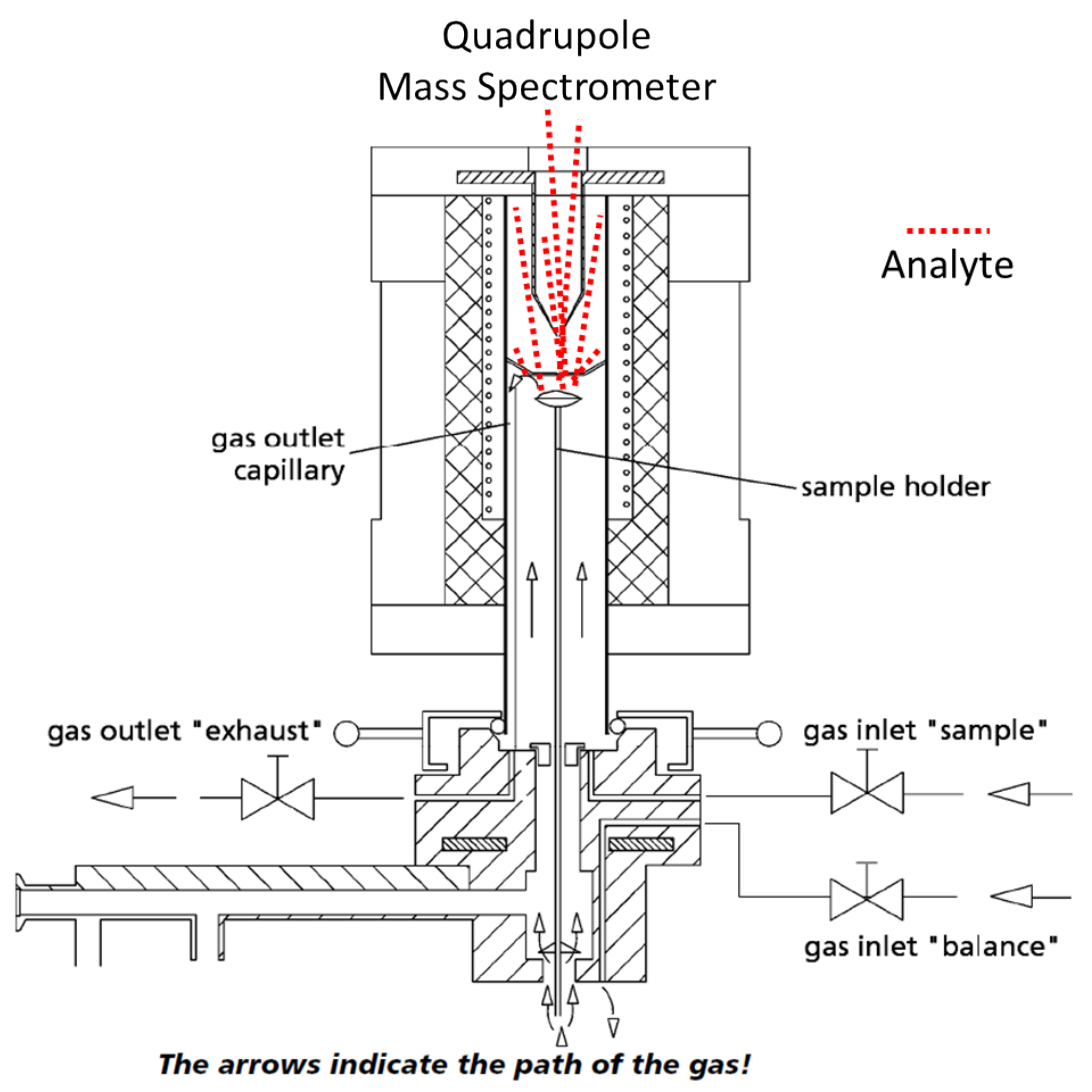

Figure 1. Schematic of Netzsch skimmer. (Adapted from Netzsch STA-MS Operating Instructions)

The skimmer can be run in various modes. One comprises a differential scanning calorimeter (DSC). The carrier for the DSC is shown in Figure 2. Two crucibles are heated simultaneously in three separate runs to acquire data:

1. The empty sample holder with a reference cell.

2. The sample holder with reference material, such as sapphire, with a reference cell.

3. The sample holder with the sample of interest, with a reference cell.

The right-hand side of Figure 2 shows a drawing of a heat shield that surrounds the sample carrier. Figure 3 shows data from a reference run with a Netzsch TGA. The temperature ramp, red line, goes from 25 to $700^{\circ} \mathrm{C}$. The mass loss is shown with the green line. Aside from slight changes in buoyancy at the beginning and the end of the run, very little mass change was observed with the sealed cells. The sample crucibles are described in Section 2.2. 


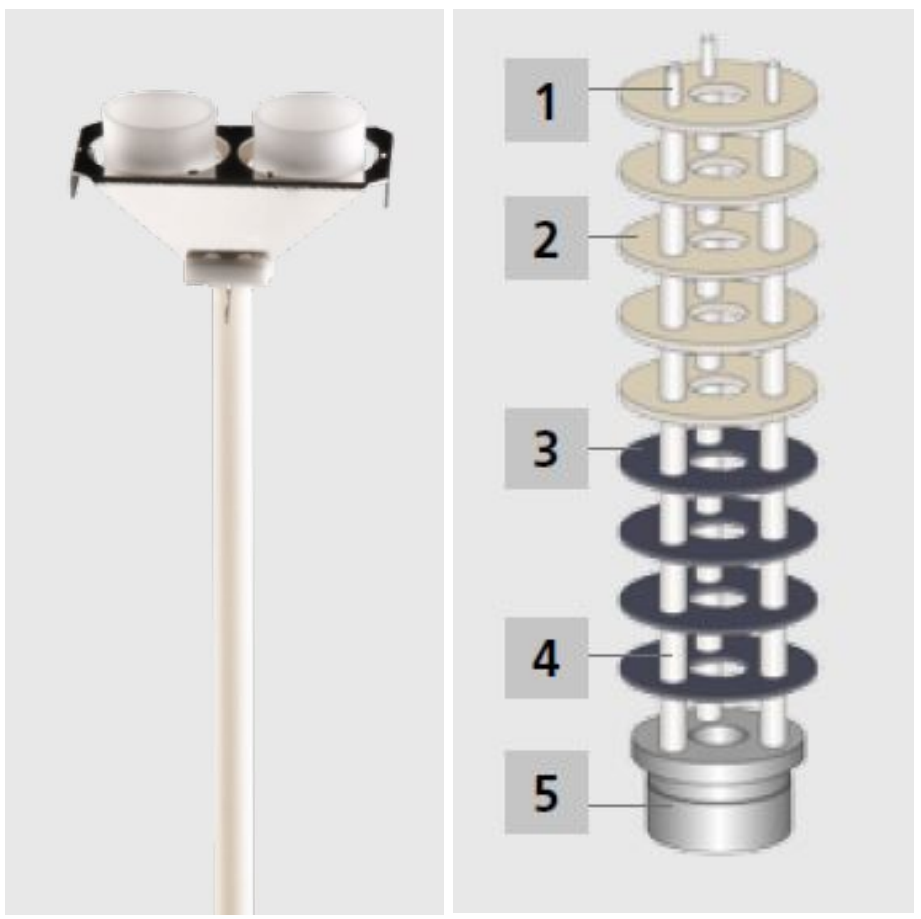

Figure 2. TG-DSC sample carrier system (on left) and heat shield (on right). (Source: Netzsch).

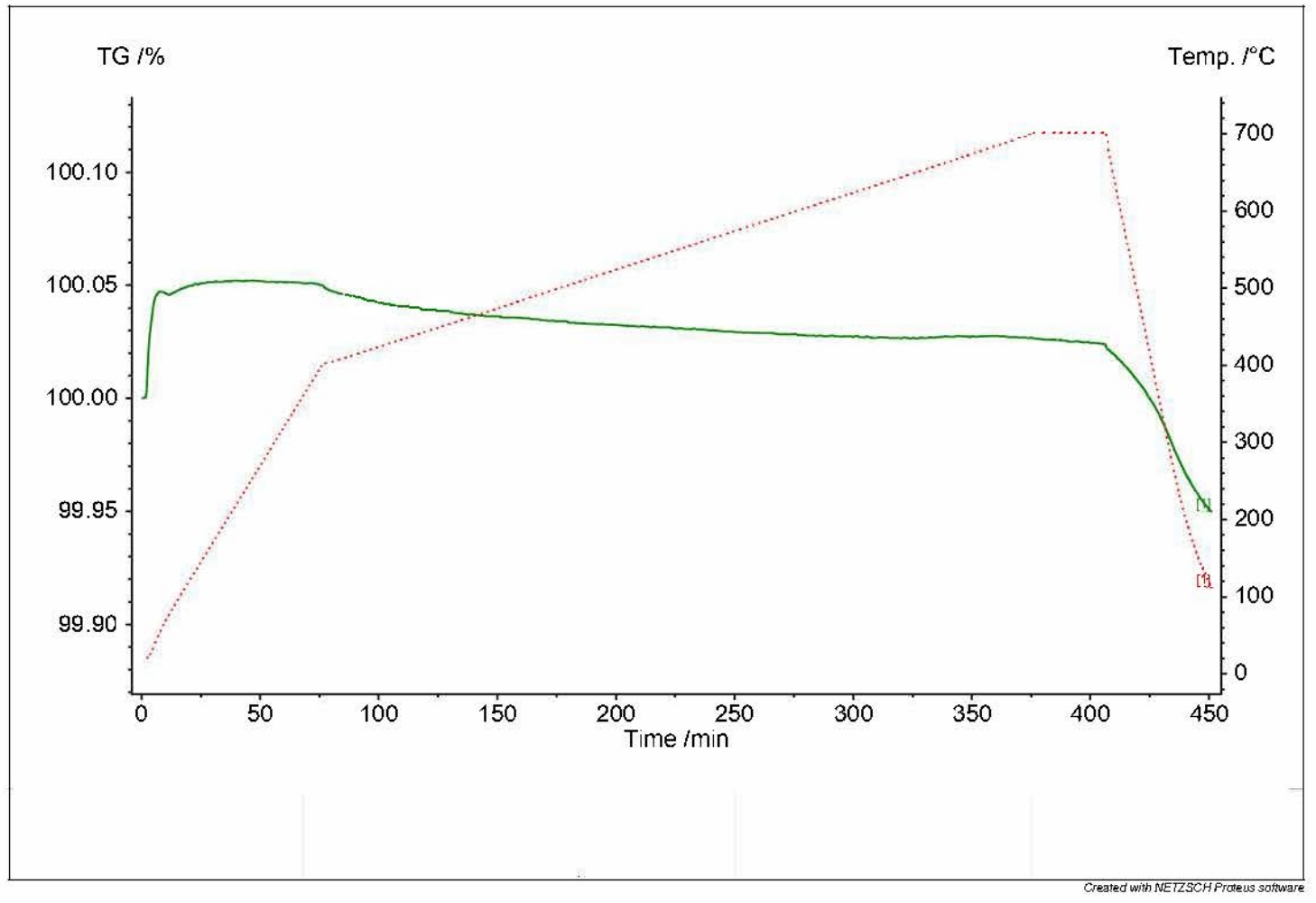

Figure 3. Mass loss test with sealable DSC crucibles up to $700^{\circ} \mathrm{C}$, with mass trace in green and temperature ramp in red (from a standard Netzsch simultaneous thermal analyzer). 
Standard procedure with a differential scanning calorimeter (DSC) involves three heating experiments: one with an empty cell as a baseline as shown in Figure 3, one with a cell and a standard reference material such as sapphire, and one with the sample itself, all done compared to a reference. An STA, or simultaneous thermal analyzer, records mass loss data as well as thermal analysis data on the same run. The difference between the STA thermal analysis mode and a stand-alone DSC is that the STA measures heat flux in relation to the reference, rather than as a temperature difference. Although this leads to higher uncertainties in the results, running as a DSC allows a quick assessment of the purity of the sample, as transition temperatures are readily available.

Direct analysis of the vapor phase also allows measurement of vapor pressure by either the Knudsen effusion or Langmuir transpiration methods. The theory has been described in detail elsewhere ${ }^{1}$ and is summarized here.

When the STA is run with a Knudsen cell arrangement, a capped crucible with a small orifice in the lid is set on a thermogravimetric stand. A Knudsen cell allows measurement of vapor pressure in the sample crucible, $p_{m}$, through Equation (1),

$$
p_{m}=\left(\frac{d m}{d t}\right) \frac{\sqrt{2 \pi R T / M}}{A}+p
$$

where $m$ is the mass of the sample that changes with time, $t ; R$ is the gas constant, $T$ is temperature in degrees $\mathrm{K}, M$ is the gram molecular mass of the volatile component, $A$ is the area of the orifice, and $p$ is the partial pressure of the volatilized gas in the measurement volume. The Knudsen equation depends on the assumptions that the flux of molecules through the orifice is low enough so as not to perturb equilibrium conditions in the crucible - a typical ratio of orifice area to sample evaporating surface area is less than 0.01 . The volatilized molecules disperse into the outer pumped vacuum chamber via effusion, which means that there is no favored direction to the flow. Hence, this condition is only fulfilled when the pressure in the inner chamber is sufficiently low, yet higher than the outer chamber. The Netzsch skimmer can operate in a vacuum, although an inert cover gas is recommended to protect the furnace when being heated.

The measured pressure can be related to the equilibrium vapor pressure through Equation (2). The unitless Clausing factor, $k$, is related to the dimensions of the orifice as shown in Equation (3), with $l$ being the length and $d$ being the diameter, respectively.

$$
\begin{gathered}
p_{e}=p_{m}\left(1+\frac{k A_{o}}{\alpha A_{\text {cell }}}-\frac{k A_{o}}{A_{\text {cell }}}\right) \\
k=0.0849\left(\frac{2 l}{d}\right)^{2}-0.4041\left(\frac{2 l}{d}\right)+0.09898
\end{gathered}
$$

Importantly, if the area of the orifice, $A_{o}$, is much less than that of the evaporating surface of the cell, $A_{\text {cell }}$, the equilibrium vapor pressure approaches the measured vapor pressure. In the skimmer, mass loss from the balance is obtained with quadrupole mass spectrometer signal, allowing correction for instrumental factors that must be used to relate signal to partial pressure. These can include geometric factors, ionization efficiency, fragmentation, and mass spectrometer efficiency, as well as the dynamics of the vaporization process that can become increasingly important at higher pressures. ${ }^{2}$ 
The skimmer can also be operated with an open crucible, with data collected by a Langmuir thermogravimetric experiment. The equation for the pressure, $p_{L}$ measured by mass loss by a Langmuir experiment, Equation (4), is very similar to Equation (1), where $A$ becomes the area of the pan holding the sample. The instrumental calibration parameter, $\alpha$, now called the evaporation constant, must be determined through calibration with a substance with a known vapor pressure and can be used to get $p_{e}$ as shown in Equation (5). ${ }^{3}$

$$
\begin{gathered}
p_{L}=\left(\frac{d m}{d t}\right) \frac{\sqrt{2 \pi R T / M}}{A} \\
p_{e}=\frac{p_{L}}{\alpha}
\end{gathered}
$$

Under stable experimental conditions (e.g., the condensed state remains in pseudoequilibrium and the sample does not become depleted), the plot of $\ln p_{m}$ versus (1/T) gives a slope that is proportional to the enthalpy of vaporization, Equation (6), with $C$ being an arbitrary constant arising from instrumental factors discussed above. The entropy of vaporization requires the absolute determination of vapor pressure from at least one temperature (Equation (7)). These second law thermodynamic data can be used to generate third law Gibbs' free energies at $289 \mathrm{~K}$ that are used in chemical speciation calculations. ${ }^{4}$

$$
\begin{gathered}
\ln p_{m}=\frac{-\Delta H_{v a p}}{R T}+C \\
\Delta S_{v a p}=\frac{-\Delta H_{v a p}}{T}+R \ln \left(\frac{p(T)}{b a r}\right)
\end{gathered}
$$




\section{APPARATUS}

Figure 4 shows the components of the Netzsch skimmer installed at Oak Ridge National Laboratory. The components include the main instrumental assembly - which includes the furnace, the quadrupole mass spectrometer, controller for the thermal analysis unit, the quadrupole mass spectrometer, and services (vacuum, power, and water), the computer running data acquisition and analysis software - and four independent direct drive mechanical pumps that back two turbo pumps. A dedicated chiller for the furnace was not purchased (lower left of Figure 4), and instead once-through cooling water is used while the unit is in operation. A gas-rack assembly has been supplied that can provide quick switching between ultra-highpurity argon, and argon- $4 \% /$ hydrogen, as well as other gases. These cylinders are equipped with low pressure regulators, maximum 2 bar on the outlet side, and pressure relief valves to minimize the chance of overpressurizing ( $>0.5$ bar) the instrument.

Figure 5 shows a labelled photograph of the installation.

\section{$2000^{\circ} \mathrm{C}$ furnace}

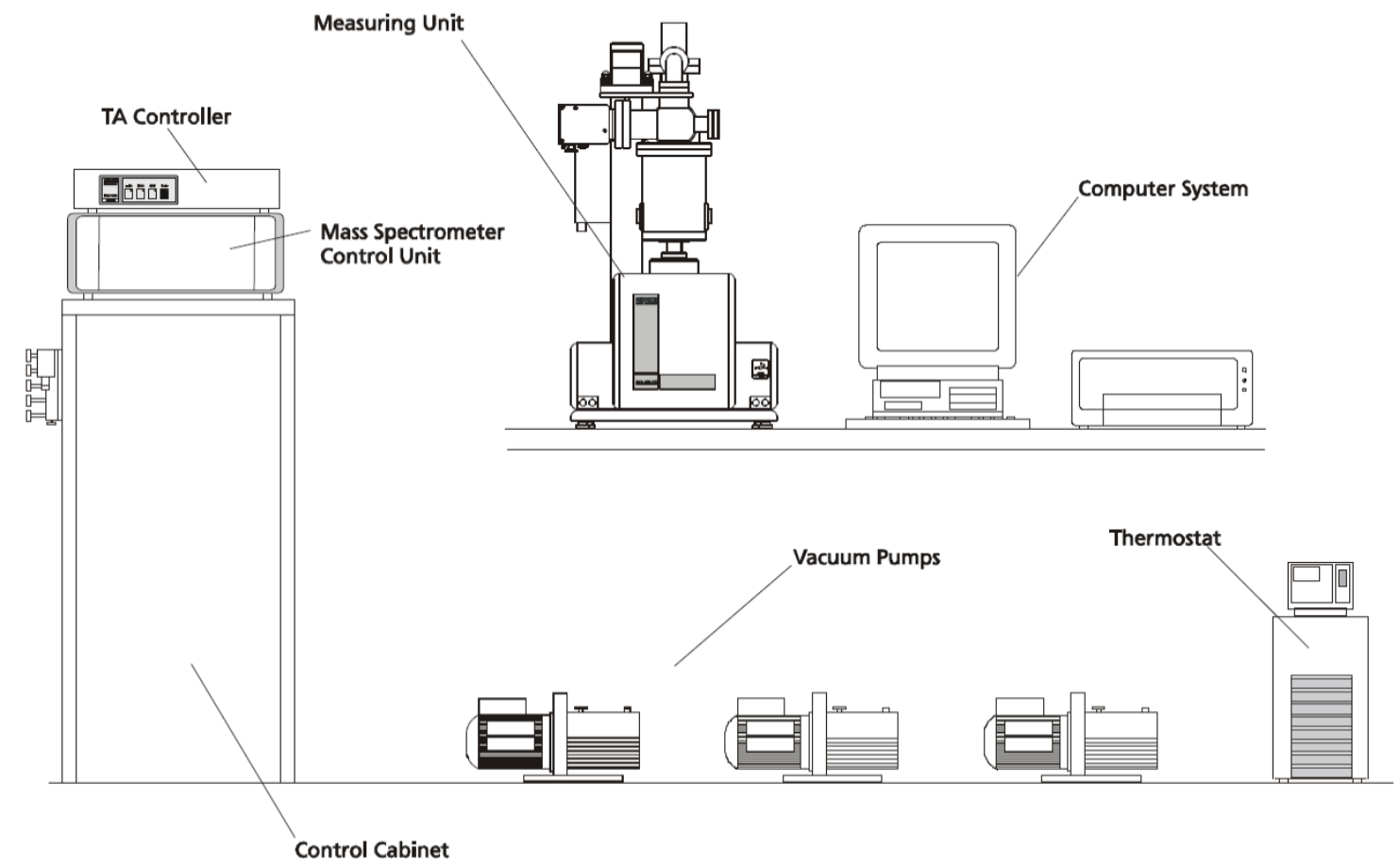

Figure 4. Elements of Netzsch skimmer including the furnace/measuring unit, control units for the mass spectrometer, balance, vacuum-water-power, pumps, and dedicated computer. (Source: Netzsch STA-MS Operating Instructions) 


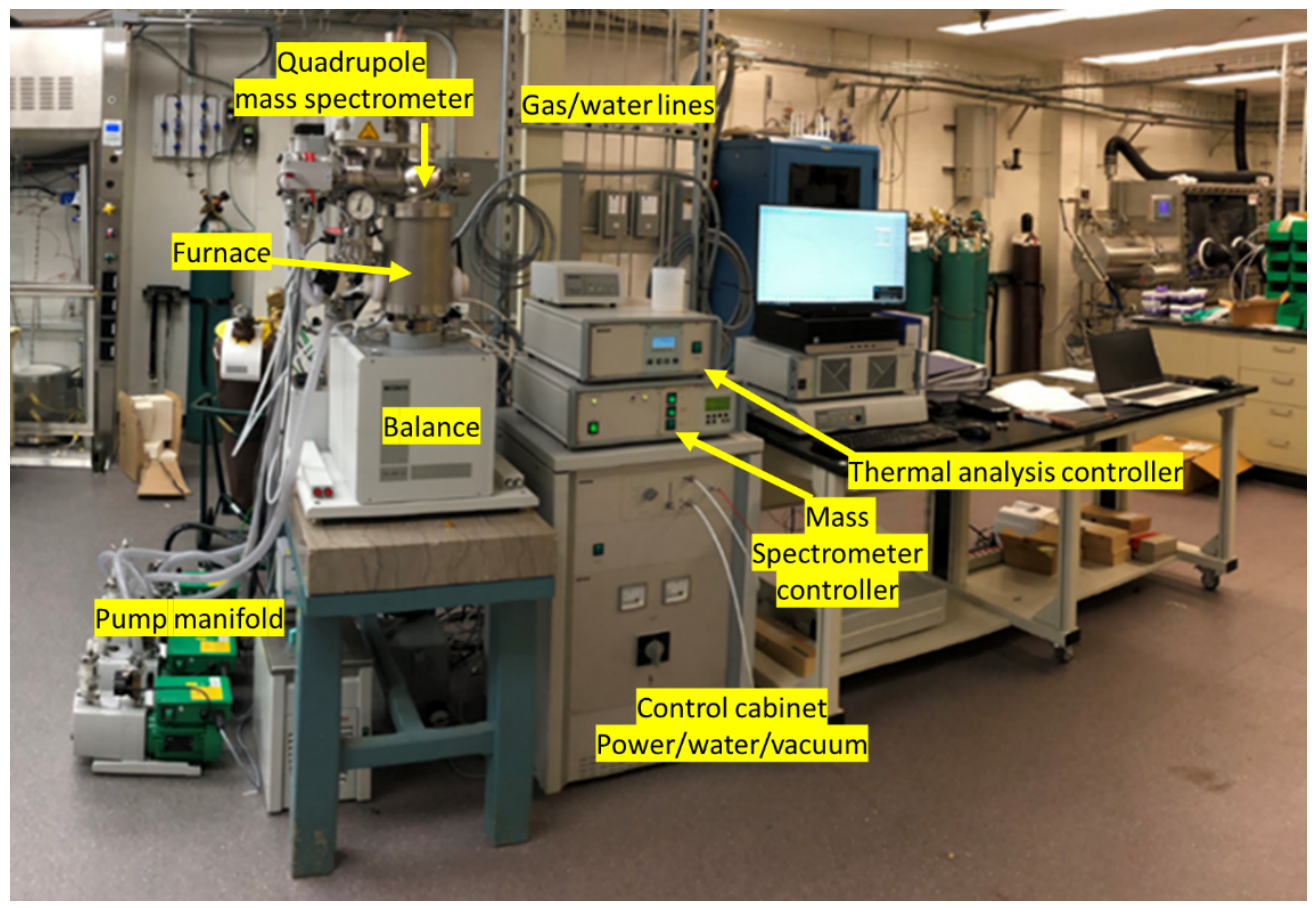

Figure 5. Photograph of the Netzsch skimmer setup at Oak Ridge National Laboratory.

Figure 6 is a photograph of the furnace as it was taken apart for the sample carrier installation. The outer skimmer is shown extending from the top flange of the furnace assembly. The quadrupole mass spectrometer is located above the furnace.

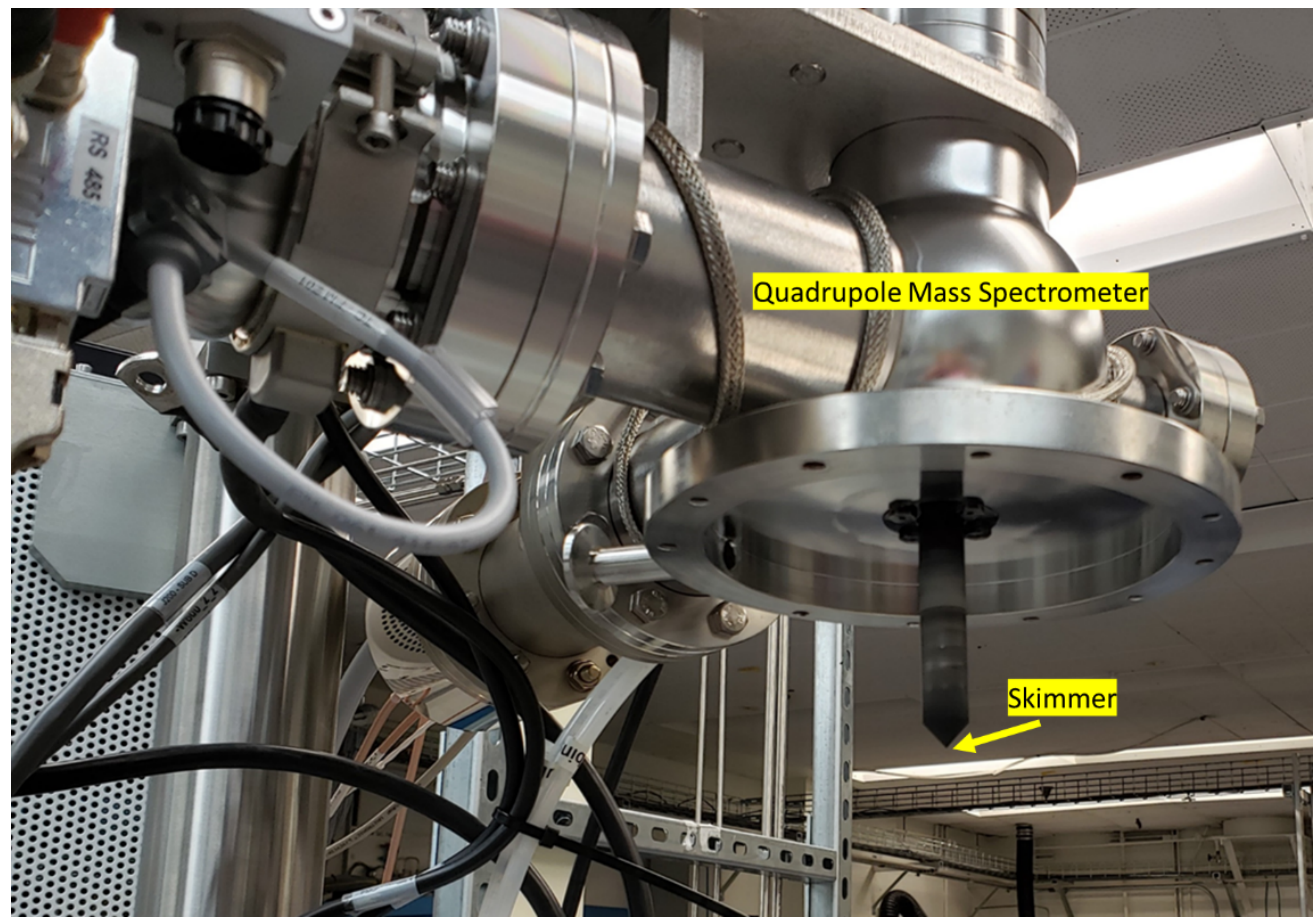

Figure 6. Netzsch STA furnace showing one of the two skimmers with the furnace dropped from the mating with the mass spectrometer. 


\subsection{METHODS OF LOADING THE SAMPLE}

For molten salts that are hygroscopic, care must be taken with the loading of sample cells. Salts are handled in a glove box that is filled with an inert atmosphere of high-purity argon. In the glove box, the salt material is weighed into the cell being used for measurement. However, the sample must then be transported into the instrument, and even under the best circumstances, will be exposed to air for a couple of minutes. A method that has been developed to prevent air ingress is to seal the crucible with paraffin (in the form of parafilm). The paraffin volatilizes below $100^{\circ} \mathrm{C}$, well below the melting point of the salt, protecting the sample when it is being handled and transported.

\subsection{SELECTION OF CRUCIBLES}

Crucibles for use in the Netzsch skimmer for heat capacity measurements are compatible with those for the standalone Netzsch DSC. Although standard crimped cells are available, sealing $\mathrm{Ni}-\mathrm{Cr}$ alloy crucibles using a Netzsch specialty torque wrench is preferred for salt measurements (Figure 7). These are not available in molybdenum that has been shown to have better corrosion resistance against molten salts. Thus, molybdenum crucibles that can be sealed using electron-beam welding are being developed for both the DSC and the skimmer. Initial testing has shown that sealing is possible, although the welds look rough (Figure 8). Rhodium is being considered as an alternative because it is both inert and more easily machined.

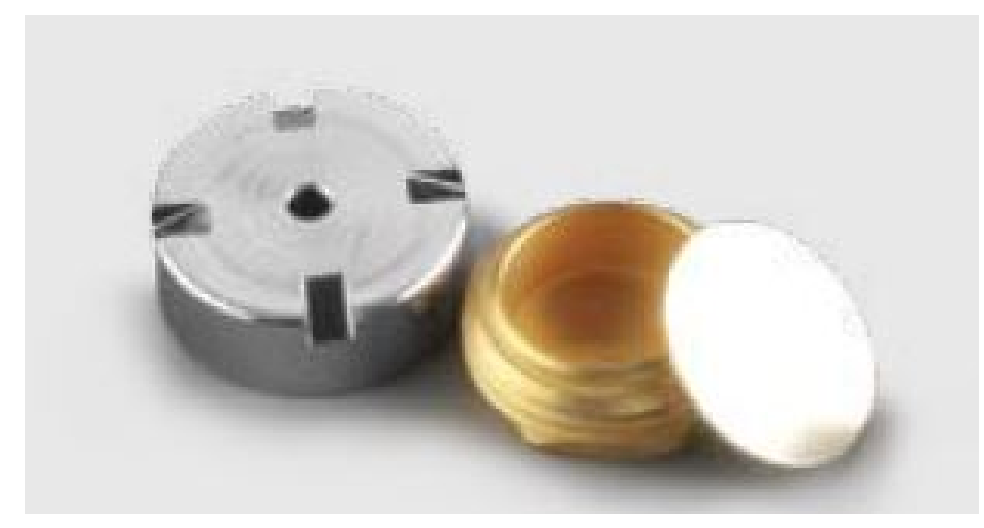

Figure 7. High-pressure, sealable Ni-Cr alloy crucible with gold-plated pan. (Source: Netzsch) 

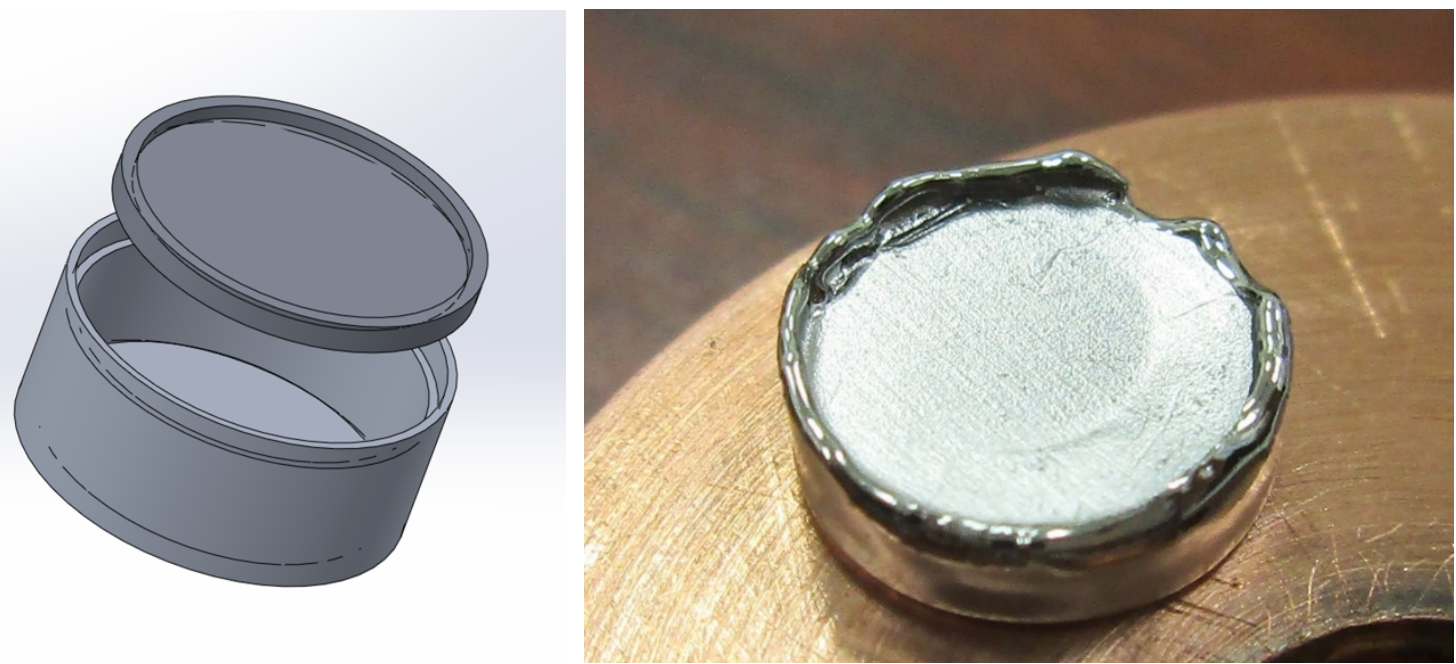

Figure 8. Schematic of sealed molybdenum crucible and electron-beam welded crucible prototype.

There are many options for sealing crucibles, including molybdenum, and inert inserts are available, such as graphite. These range in size from $27 \mu \mathrm{L}$ to $300 \mu \mathrm{L}$, and even larger sizes are available, depending on the application. For most of the skimmer experiments, the smallest sized crucibles are sufficient. Some of the sample crucibles are listed in Table 1 below. Netzsch can supply carriers for each type of crucible. The crucibles are meant to be reusable depending on the application, although the liners or sealing disks may not be. Welded crucibles would not be reusable, although a sample could be thermally cycled more than once to observe if it changes over time. 
Table 1. Selected sample crucibles for the Netzsch STA.

\begin{tabular}{|l|l|l|l|}
\hline Material of construction & \multicolumn{1}{|c|}{$\begin{array}{c}\text { Maximum temperature } \\
\left({ }^{\circ} \mathbf{C}\right)\end{array}$} & \multicolumn{1}{c|}{ Shape } & \multicolumn{1}{c|}{$\begin{array}{c}\text { Capacity }(\boldsymbol{\mu L}) \text { unless } \\
\text { noted otherwise }\end{array}$} \\
\hline $\mathrm{Al}_{2} \mathrm{O}_{3}$ & 1650 & $\begin{array}{l}\text { Open cup, TG-DTA } \\
\text { Thin-walled }\end{array}$ & 200 \\
\hline $\mathrm{Al}_{2} \mathrm{O}_{3}$ & 1650 & $\begin{array}{l}\text { Open cup, TG-DTA } \\
\text { Thick-walled }\end{array}$ & 200 \\
\hline $\mathrm{Al}_{2} \mathrm{O}_{3}$ & 1650 & Open cup, TG-DTA & 300 \\
\hline $\mathrm{Al}_{2} \mathrm{O}_{3}$ & 1650 & Lids & Sized appropriately \\
\hline $\mathrm{Pt}-\mathrm{Ir}$ & 1650 & Open cup, TG-DTA & 300 \\
\hline $\mathrm{Ta}$ & 1650 & Open cup, TG-DTA & 300 \\
\hline $\mathrm{Graphite}$ & 1650 & Open cup, TG-DTA & 300 \\
\hline $\mathrm{Nickel}$ & 1300 & Open cup, TG-DTA & 300 \\
\hline $\mathrm{Stainless} \mathrm{steel}$ & 1000 & Open cup, TG-DTA & 300 \\
\hline $\mathrm{Quartz}$ & 1000 & Ampoule & 1300 \\
\hline $\mathrm{Al}{ }_{2} \mathrm{O}_{3}$ & 1650 & Large cup, TG & $3.4 \mathrm{~mL}$ \\
\hline $\mathrm{Al}{ }_{2} \mathrm{O}_{3}, \mathrm{Pt}$ & 1650 & plate & $10 \mathrm{~mm}$ diameter \\
\hline $\mathrm{Quartz}$ & 1100 & Sample pan for DSC & 85 \\
\hline $\mathrm{Quartz}$ & 1100 & Lid for DSC pan & $6.7 \mathrm{~mm}$ diameter \\
\hline $\mathrm{Graphite}$ & $1650-2000$ & Sample pan for DSC & 85 \\
\hline $\mathrm{Pt}-\mathrm{Rh}$ & 1500 & Sample pan for DSC & 85 \\
\hline $\mathrm{Al}{ }_{2} \mathrm{O}_{3}$ & & Liner for DSC sample pan & Sized appropriately \\
\hline $\mathrm{Cr}-\mathrm{Ni}$ steel & 500 & $\begin{array}{l}\text { Lidded crucible for } \\
\text { pressure }\end{array}$ & 27 \\
\hline $\mathrm{Au}$ & Sealing discs & Sized appropriately \\
\hline
\end{tabular}




\section{COMMISSIONING}

Instrument operation was tested using calcium oxalate. Details for operation and maintenance are provided in the manuals for the instrument. $5,6,7$ This material shows reproducible mass loss traces that can be used to test operation of the balance. Calcium oxalate, $\mathrm{Ca}^{2+} \cdot\left[\mathrm{C}_{2} \mathrm{O}_{4}\right]^{2-}$, is a salt that decomposes when heated, liberating $\mathrm{CO}$ and $\mathrm{CO}_{2}$. These can be tracked in the mass spectrometer to evaluate its operation. The calcium oxalate was heated in an alumina cell to $935^{\circ} \mathrm{C}$. Data from the skimmer are shown in Figures 9 and 10, which show the mass loss trace and ion signals, respectively. The mass loss data, shown as the blue trace below, has a slight slope on the baseline that indicates the skimmer had not been sufficiently equilibrated before the run. Normally, the cooling water should be circulated overnight before starting a run.

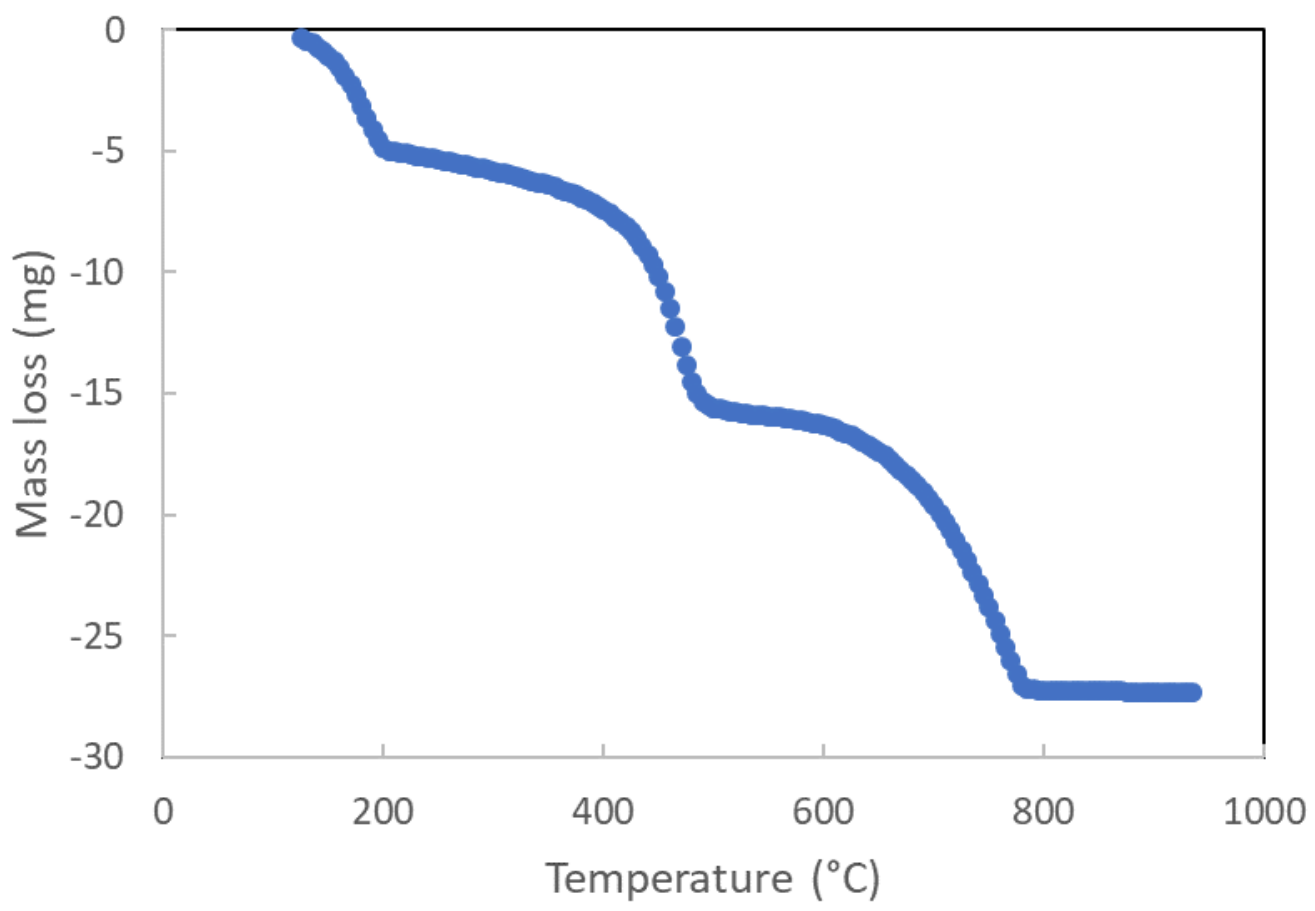

Figure 9. Mass loss trace from the heating of calcium oxalate in commissioning the skimmer.

Selected ion signals for volatile species observed during the decomposition of calcium oxalate are shown in Figure 10. Mass 44 (blue points), which corresponds to $\mathrm{CO}_{2}$, and mass 28 (grey points), which corresponds to $\mathrm{CO}$, track each other. Mass 32 (orange points), as well as mass 14 (for $\mathrm{N}$ atoms) and mass 16 (for $\mathrm{O}$ atoms) that are not included on Figure 10, show little change during the heating phase, suggesting that these arise from residual gases in the vacuum system. Mass 28, therefore, is actually a combination of signal from $\mathrm{N}_{2}$ and from $\mathrm{CO}$, but the dramatic changes in signal observed during the temperature ramp are from $\mathrm{CO}$. The baseline from $\mathrm{N}_{2}$ shows the same slow decline as observed for $\mathrm{O}_{2}$, although this is more apparent at temperatures below $200^{\circ} \mathrm{C}$. The instrument was set up to collect data for each ion in sequence, and then to rotate back and start over, all the while the temperature is ramping up. Thus, the more mass-tocharge ratios that are selected, the longer it will take the data acquisition system to complete measurements on the selected ions, and the greater the discrepancy in temperature across the range of ions. Although a complete scan of several hundred atomic mass units is possible, this is not recommended during a temperature ramp. It would be feasible for an isothermal analysis, though. 


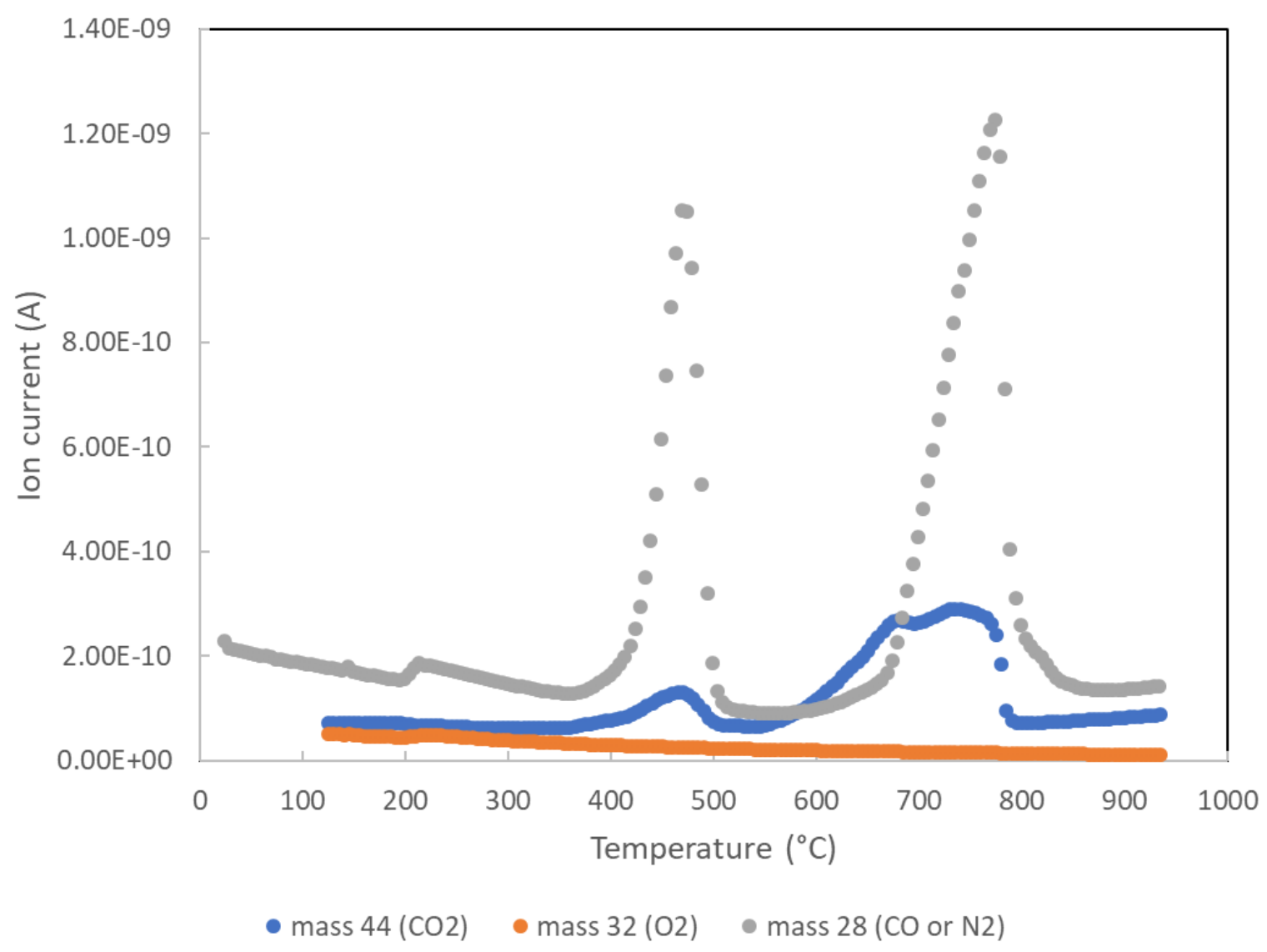

Figure 10. Ion signal as a function of temperature for calcium oxalate. 


\section{FUTURE PLANS}

The Netzsch skimmer will be an important part of the experimental program investigating the chemistry of molten salts in support of the advanced reactor campaign. Some of the salt systems that will be investigated are listed in Table 2. These have been selected to support molten salt purification efforts, to assess salt purities before corrosion tests, and to support the collection of fundamental thermodynamic data. This table is representative of the salts that will be studied. It is not meant to be complete, and we expect to update the list as priorities in the program shift.

Table 2. Possible salt mixtures for near-term study in the skimmer

\begin{tabular}{|c|c|}
\hline Project & Salt mixture \\
\hline \multirow{3}{*}{ Skimmer test } & $\mathrm{NaCl}: \mathrm{KCl}$ \\
\hline & $\mathrm{KCl}: \mathrm{MgCl}_{2}$ \\
\hline & $\mathrm{LiCl}: \mathrm{KCl}$ \\
\hline Solar program & $\mathrm{NaCl}: \mathrm{KCl}: \mathrm{MgCl}_{2}$ \\
\hline Fission product source term & $\mathrm{I}_{2}, \mathrm{ICl}$ in $\mathrm{NaCl}: \mathrm{KCl}$ \\
\hline Department of Energy campaign & HF in FLiNaK \\
\hline Off-gas & REfluorides/chlorides \\
\hline Actinide studies & Uranium-bearing salts \\
\hline Department of Energy campaign & Plutonium-bearing salts \\
\hline Thermodynamics & Lanthanides: $\mathrm{CsCl}-\mathrm{MgCl}_{2}+\mathrm{EuCl}_{3} / \mathrm{SmCl}_{3}$ \\
\hline \multirow{3}{*}{ Fission product volatility } & FLiNaK \\
\hline & Iodine fluoride + FLiNaK \\
\hline & Tellurium fluoride + FLiNaK \\
\hline \multirow{4}{*}{$\begin{array}{l}\text { Meitner project } \\
\text { fission product volatility }\end{array}$} & Cs, I volatility \\
\hline & Fuel salt (uranium, etc.) $+\mathrm{NaCl}$ \\
\hline & Coolant salt $\left(\mathrm{ZrF}_{4}+\right.$ impurities $)$ \\
\hline & Concrete $(\mathrm{CaO})\left(\mathrm{SiO}_{2}\right)\left(\mathrm{H}_{2} \mathrm{O}\right)+\mathrm{Ca}(\mathrm{OH})_{2}$ \\
\hline \multirow{3}{*}{ Molten Chloride Fast Reactor salt } & Coolant salt \\
\hline & Fuel salt with uranium \\
\hline & Fuel salt with plutonium \\
\hline \multirow{2}{*}{ X-ray } & $\mathrm{KCl}-\mathrm{MgCl}_{2}$ \\
\hline & Added $\mathrm{Cr}(\mathrm{II}), \mathrm{Cr}(\mathrm{III})$ \\
\hline \multirow{2}{*}{ Corrosion studies } & $\mathrm{NaCl}-\mathrm{CrCl}_{2}$ \\
\hline & $\mathrm{NaCl}-\mathrm{CrCl}_{3}$ \\
\hline Isotope separation & $\mathrm{NaCl}-\mathrm{MgCl}_{2}+$ molybdenum \\
\hline Fluoride volatility & FLiNaK + molybdenum \\
\hline \multirow{3}{*}{ Thermophysical properties, density } & $\mathrm{NaCl}$ reference \\
\hline & FLiNaK \\
\hline & $\mathrm{KCl}-\mathrm{MgCl}_{2}$ \\
\hline \multirow{2}{*}{ U redox state } & $\mathrm{U}(\mathrm{III}), \mathrm{U}(\mathrm{IV}), \mathrm{Ce}(\mathrm{III}), \mathrm{Ce}(\mathrm{IV})$ \\
\hline & Magnetite, ferrite \\
\hline
\end{tabular}




\section{CONCLUSIONS}

A Netzsch skimmer has been commissioned at Oak Ridge National Laboratory. The versatile instrument can be operated in three modes. The thermogravimetric analyzer provides data on mass change, mass loss associated with volatilization, and mass gain if the sample is exposed to a reactive gas. The DSC gives transition temperatures, reaction energies and transition energies. It can be used for heat capacity measurements, although with less accuracy than stand-alone DSC instruments. Volatiles from samples can be measured directly using a differentially pumped quadrupole mass spectrometer. The line of sight to the mass spectrometer is heated to minimize condensation, and the differential pumping allows evolved gas measurements to be taken simultaneously with sample heating. This new capability will permit identification of the evolved gas. Coupling of evolved gas analysis to thermogravimetric measurements will allow determination of vapor pressures that will be used to generate thermodynamic data on multicomponent molten salt systems. 


\section{ACKNOWLEDGMENTS}

This work was funded by the Department of Energy Office of Nuclear Energy's Advanced Reactor Campaign. This manuscript has been authored by UT-Battelle, LLC, under contract DE-AC0500OR22725 with the US Department of Energy (DOE).

\subsection{CONTACT INFORMATION FOR NETZSCH}

Netzsch Incorporated

119 Pickering Way

USA-Exton, PA 19341-1393

Telephone 215-363-8010, 215-363-8011 


\section{REFERENCES}

1. McMurray, J. W., Frame, B. J., Voit, S. L. 2018. "Vaporization behavior of an alkyl diphenyl ether and a commercial lubricant," Vacuum 155, 43-38

2. McFarlane, J., Wren, J. C., Lemire, R. L. 2002. "Chemical speciation of iodine source term to containment," Nuclear Technology 138, 162-178.

3. McMurray, J. W., Zhou, Y., Luo, H. M., Qu, J. 2017. "Vaporization behavior of tetraoctylphosphonium bis(2-ethylhexyl)phosphate ionic liquid," Chemical Physics Letters, 667, 5561.

4. McFarlane, J., "Fission product tellurium chemistry from fuel to containment." In Proceedings of the 4th OECD/CSNI Workshop on the Chemistry of Iodine in Reactor Safety, Würenlingen, Switzerland, June 10-12, 1996.

5. Netzsch, Operating Instructions. Simultaneous Thermal Analysis Instrument, STA 409 C.

6. Netzsch, Supplemental Instruction Manual. STA-MS Skimmer Coupling System, STA 409 CD $/ 403 / 5 / \mathrm{G}$.

7. Netzsch, Operating Instructions. Simultaneous Thermal Analysis, STA 409 CD. 